\title{
Distinct behavior of bovine-associated staphylococci species in their ability to resist phagocytosis and trigger respiratory burst activity by blood and milk polymorphonuclear leukocytes in dairy cows
}

\author{
Rodrigo M. Souza, ${ }^{1 *}$ Fernando N. Souza, ${ }^{1,2,3 *} \dagger$ Camila F. Batista, ${ }^{1}$ Sofie Piepers, ${ }^{2}$ Anneleen De Visscher, ${ }^{2}$ \\ Kamila R. Santos, ${ }^{1}$ Paula C. Molinari, ${ }^{1,4}$ José A. Ferronatto, ${ }^{1}$ Adriano Franca da Cunha, ${ }^{5}$ Maiara G. Blagitz, ${ }^{1,6}$ \\ Guilherme G. da Silva, ${ }^{7}$ Francisco P. Rennó, ${ }^{7}$ Mônica M. O. P. Cerqueira, ${ }^{5}$ Marcos B. Heinemann, ${ }^{8}$ \\ Sarne De Vliegher, ${ }^{2}$ and Alice M. M. P. Della Libera ${ }^{1}$ \\ ${ }^{1}$ Veterinary Clinical Immunology Research Group, Departamento de Clínica Médica, Faculdade de Medicina Veterinária e Zootecnia, \\ Universidade de São Paulo, Av. Prof. Dr. Orlando Marques de Paiva 87, São Paulo 05508-270, Brazil \\ ${ }^{2}$ M-team and Mastitis and Milk Quality Research Unit, Department of Reproduction, Obstetrics and Herd Health, Faculty of Veterinary Medicine, \\ Ghent University, Salisburylaan 133, Merelbeke 9820, Belgium \\ ${ }^{3}$ Programa de Pós-graduação em Ciência Animal, Universidade Federal da Paraíba, Areia 58397-000, Brazil \\ ${ }^{4}$ Department of Animal Sciences, University of Florida, Gainesville 32611-0910 \\ ${ }^{5}$ Departamento de Tecnologia e Inspeção de Produtos de Origem Animal, Escola de Veterinária, Universidade Federal de Minas Gerais, \\ Belo Horizonte 31270-010, Brazil \\ ${ }^{6}$ Curso de Medicina Veterinária da Universidade Federal da Fronteira Sul e Programa de Pós-Graduação em Saúde, \\ Bem-estar e Produção Animal Sustentável na Fronteira Sul, Campus Realeza, Realeza 85770-000, Brazil \\ ${ }^{7}$ Departamento de Nutrição e Produção Animal, Faculdade de Medicina Veterinária e Zootecnia, Universidade de São Paulo, \\ Pirassununga 13635-900, Brazil \\ ${ }^{8}$ Departamento de Medicina Veterinária Preventiva e Saúde Animal, Faculdade de Medicina Veterinária e Zootecnia, Universidade de São Paulo, \\ São Paulo 05508-270, Brazil
}

\section{ABSTRACT}

Mastitis affects a high proportion of dairy cows and is still one of the greatest challenges faced by the dairy industry. Staphylococcal bacteria remain the most important cause of mastitis worldwide. We investigated how distinct staphylococcal species evade some critical host defense mechanisms, which may dictate the establishment, severity, and persistence of infection and the outcome of possible therapeutic and prevention interventions. Thus, the present study investigated variations among distinct bovine-associated staphylococci in their capability to resist phagocytosis and to trigger respiratory burst activity of blood and milk polymorphonuclear neutrophil leukocytes (PMNL) in dairy cows. To do so, PMNL of 6 primiparous and 6 multiparous dairy cows were used. A collection of 38 non-aureus staphylococci (NAS) and 12 Staphylococcus aureus were included. The phagocytosis and intracellular reactive oxygen species (ROS) production by blood and milk PMNL were analyzed by flow cytometry. Phagocytosis, by both blood and milk PMNL, did not differ between $S$. aureus and NAS as a group, although

Received July 1, 2021.

Accepted October 9, 2021.

*These authors contributed equally to this work.

†Corresponding author: nogueirasouza@yahoo.com.br
within-NAS species differences were observed. Staphylococcus chromogenes (a so-called milk-adapted NAS species) better resisted phagocytosis by blood PMNL than the so-called environmental (i.e., Staphylococcus fleurettii) and opportunistic (i.e., Staphylococcus haemolyticus) NAS species. Otherwise, S. haemolyticus was better phagocytosed by blood PMNL than $S$. aureus, $S$. fleurettii, and $S$. chromogenes. No influence of the origin of the isolates within the staphylococci species in the resistance to phagocytosis by blood and milk PMNL was found. Overall, both S. aureus and NAS did not inhibit intracellular ROS production in blood and milk PMNL. Non-aureus staphylococci induced fewer ROS by milk PMNL than $S$. aureus, which was not true for blood PMNL, although species-specific differences in the intensity of ROS production were observed. Staphylococcus chromogenes induced more blood PMNL ROS than $S$. fleurettii and S. haemolyticus, and as much as $S$. aureus. Conversely, S. chromogenes induced fewer milk PMNL ROS than $S$. aureus. The origin of the isolates within the staphylococci species did not affect the ROS production by blood and milk PMNL. In conclusion, our study showed differences in staphylococci species in evading phagocytosis and triggering ROS production, which may explain the ability of some staphylococci species (i.e., S. aureus and S. chromogenes) to cause persistent infection and induce inflammation.

Key words: mastitis, Staphylococcus aureus, nonaureus staphylococci, neutrophil, dairy cattle 


\section{INTRODUCTION}

Staphylococci are part of the skin microbiota of mammals and have been isolated from various body sites of dairy cows and from the dairy environment. They are also the most common cause of bovine IMI (Adkins et al., 2018; Leuenberger et al., 2019; Wuytack et al., 2019). Among the genus Staphylococcus, Staphylococcus aureus is one of the so-called major mastitis pathogens that represent a real issue for bovine udder health because of their pathogenicity, contagiousness, poor cure rates with current antimicrobial therapies, and public health concerns (Moura et al., 2018; Rainard et al., 2018; Cunha et al., 2020). Intramammary infections caused by $S$. aureus are also associated with the highest economic losses among all mastitis pathogens (Halasa et al., 2009). Furthermore, the epidemiology of $S$. aureus markedly depends on the genotype, with some being adapted to a particular host and even to a particular body site (Leuenberger et al., 2019).

The role of the heterogeneous group of NAS in bovine mastitis is still being debated. The bovine-associated NAS species cover a broad range of ecological habitats, varying from primarily the environment (e.g., Staphylococcus fleurettii) to the cows' udder (e.g., Staphylococcus chromogenes; De Visscher et al., 2014; Vanderhaeghen et al., 2014, 2015). In this regard, substantial variations among and within bovine-associated NAS species in evoked inflammation as measured through the SCC, persistence of IMI, presence of antimicrobial resistance, pathogenicity, and epidemiological behavior have been reported (Vanderhaeghen et al., 2015; Souza et al., 2016b; Piccart et al., 2016).

Polymorphonuclear neutrophil leukocytes (PMNL) are critical to limit pathogen survival and dissemination through their ability to phagocytose and kill invading bacteria, also in the bovine udder. When PMNL are recruited from blood to the mammary compartment, they phagocytose bacteria through oxygen-dependent and oxygen-independent mechanisms. The generation of reactive oxygen species (ROS) represents their main arsenal against invading bacteria (Rinaldi et al., 2007; Blagitz et al., 2013; Della Libera et al., 2015). Although it is known that PMNL provide the first line of defense against invading bovine mastitis-causing pathogens (Paape et al., 2003), almost nothing is known about the variations among staphylococci in their ability to resist bovine PMNL.

Bacteria invading the mammary gland are constantly exposed to milk resident PMNL, fueled by the rapid influx of neutrophils from the blood in an attempt of the host to eliminate the invading pathogen. To counter the host defense mechanisms, pathogens use several strategies to subvert the immune response, including the phagocytic and killing mechanisms of neutrophils. Therefore, it is reasonable to speculate that long coevolution of microorganisms and host immune cells may be involved in the selection of microorganisms that are well adapted to the host, which could dictate the establishment, severity, and persistence and outcome of possible therapeutic and prevention interventions (Spaan et al., 2013; Horn et al., 2018). Thus, the present study explored variations in the ability of distinct bovine-associated staphylococcal ( $S$. aureus and NAS) species and whether their ecological niche origin affects their ability to resist phagocytosis and to trigger respiratory burst activity by blood and milk resident PMNL in primiparous and multiparous dairy cows.

\section{MATERIALS AND METHODS}

This study was approved by the Animal Research Ethics Committee of the Faculty of Veterinary Medicine and Animal Science, University of São Paulo (protocol number: 88010080715).

\section{Staphylococcal Isolates}

Twelve Staphylococcus aureus isolates originating from aseptically collected milk samples $(\mathrm{n}=6)$ and noses $(\mathrm{n}=6)$ obtained from 2 Brazilian dairy herds (Souza et al., 2016a; Cunha et al., 2020; Santos et al., 2020) were available. These isolates were previously identified phenotypically by biochemical tests (Souza et al., 2016a), confirmed by MALDI-TOF MS and molecular identification targeting a portion of the conserved $S$. aureus thermonuclease gene (Santos et al., 2020). Additionally, a collection of 38 different NAS isolates obtained from 13 Flemish dairy herds during previous studies (Piessens et al., 2011; Supré et al., 2011; De Visscher et al., 2016) was available as well: $5 S$. chromogenes isolates originating from teat apices (TA; De Visscher et al., 2016), 10 S. chromogenes isolates originating from aseptically collected milk samples (Supré et al., 2011), 5 Staphylococcus haemolyticus isolates originating from TA (De Visscher et al., 2016), $5 S$. haemolyticus isolates from aseptically collected milk samples (Supré et al., 2011), 5 S. fleurettii isolates originating from aseptically collected milk samples (Supré et al., 2011), and 8 S. fleurettii isolates originating from cows' environment (Piessens et al., 2011). Non-aureus staphylococci isolates from TA and milk samples were previously identified by transfer RNA intergenic spacer PCR (Supré et al., 2011; De Visscher et al., 2016), and if no identification could be obtained, sequencing of the 16S rRNA gene was performed (De Visscher et al., 2016). Staphylococcus fleurettii isolates originating from cows' environment were previously identified at species 
level by comparison of amplified fragment length polymorphism fingerprints to a staphylococcal library or by rpoB gene sequencing (Piessens et al., 2011).

\section{Growth Conditions for Bactericidal Killing and Phagocytosis Assays}

The bactericidal killing and phagocytosis assay were assessed using unlabeled and labeled bacteria, respectively. First, the isolates were grown on $5 \%$ sheep blood agar plates. Then, fresh colonies of each bacteria were grown overnight in brain heart infusion (BHI, catalog no. 1135 , ThermoFisher) broth at $37^{\circ} \mathrm{C}$. Subsequently, all staphylococci isolates were diluted at 1:1,000 and overnight cultured at $37^{\circ} \mathrm{C}$ in fresh $\mathrm{BHI}$ broth. Then, the bacteria in the late exponential growth were centrifuged at 2,500 $\times g$ for $15 \mathrm{~min}$ at $4^{\circ} \mathrm{C}$ and washed twice with Dulbecco's PBS (catalog no. 14190185, Gibco). Afterward, bacteria were resuspended in RPMI-1640 (catalog no. R7638, Sigma Aldrich) with 10\% heatinactivated fetal bovine serum (Cultilab), and stored at $-80^{\circ} \mathrm{C}$ for a maximum of $7 \mathrm{~d}$. The bacterial suspensions were further cultured on BHI agar plates in dilution series, and counts $\left(\mathrm{cfu} \cdot \mathrm{mL}^{-1}\right)$ were determined. Then, the bacterial concentration was adjusted to the final inoculum dose $\left(2 \times 10^{8}\right.$ staphylococci $\left.\cdot \mathrm{mL}^{-1}\right)$. Further, 31.25 and $25 \mu \mathrm{L}$ of the inoculum with unlabeled staphylococci were added to the blood and milk cells, respectively, to study intracellular ROS production by PMNL, to obtain an approximate multiplicity of infection (MOI) of 25 for blood PMNL and viable milk cells each. Afterward, to ensure the bacteria viability in the stock solution, aliquots of the suspension of each isolate were serially diluted on BHI agar before freezing at $-80^{\circ} \mathrm{C}$ and at the day of the experiment.

\section{5(6)-Carboxyfluorescein Diacetate N-Succinimidyl Ester Labeling Bacteria for Phagocytosis Assay}

For the assessment of the phagocytosis assay, the $5(6)$-carboxyfluorescein diacetate $\mathrm{N}$-succinimidyl ester (CFSE)-labeled live staphylococcal isolates were prepared as previously described by Vander Top et al. (2006) and Sousa Marques et al. (2021). Briefly, the bacterial suspension was incubated at $37^{\circ} \mathrm{C}$ for 30 min in the dark with an equal volume of a 2.0 $\mu M$ solution of CFSE (catalog no. C1157, Invitrogen). Afterward, the bacterial suspensions were centrifuged at $10,000 \times g$ for $10 \mathrm{~min}$ at $4^{\circ} \mathrm{C}$ and washed 3 times with Dulbecco's PBS (catalog no. 14190185, Gibco), and further resuspended in RPMI-1640 (catalog no. R7638, Sigma Aldrich) with 10\% heat-inactivated fetal bovine serum (Cultilab), and stored at $-80^{\circ} \mathrm{C}$ for a maximum of $7 \mathrm{~d}$.
Thereafter, the CFSE labeling of bacteria was confirmed using flow cytometry (Supplemental Figure S1; https://figshare.com/articles/figure/Supplemental_Fig _1_Souza_JDS_2021_jpg/14877834; de Souza et al., 2021). To ensure that the bacteria viability was not affected by CFSE labeling, an aliquot of the suspension of each Staphylococcus species was serially diluted on BHI agar before and after bacteria labeling, and at the day of experiment to check if the viability of the stock solution was altered. Afterward, bacteria samples were randomized and codified (numbered), and the phagocytosis and intracellular ROS production were carried out without knowledge of the staphylococci information. Here, 31.25 and $25 \mu \mathrm{L}$ of the CFSE-labeled bacteria inoculum were added to the blood and milk cells, respectively, to obtain an approximate MOI of 25 for blood PMNL and viable milk cells.

\section{Opsonization of Bacteria}

First, the autologous blood bovine serum was complement inactivated through heat treatment (incubation for $30 \mathrm{~min}$ at $56^{\circ} \mathrm{C}$ ). Afterward, for bacteria opsonization, the live staphylococci were incubated during 20 min at $37^{\circ} \mathrm{C}$ with $10 \%$ autologous blood bovine complement-inactivated serum (Barrio et al., 2000).

\section{Animals and Samples}

Peripheral blood and milk samples were aseptically collected from 6 primiparous and 6 multiparous lactating Holstein cows at the dairy farm of the University of São Paulo located at Pirassununga, Brazil. The following mastitis control practices for the herd were adopted during milking: forestripping milk in a strip cup to diagnose clinical mastitis, pre-dipping (based on a combination of hydrogen peroxide and acid lactic, C-TEC), and drying teats with a paper towel. After milking, postdipping (based on acid lactic, C-TEC) was used. Blanket dry cow therapy and clinical mastitis treatments were also applied. Dairy cows were selected based on their previous monthly quarter SCC and bacteriological results. Furthermore, all cows met the following inclusion criteria: (1) > 21 DIM; (2) none of the quarters showed clinical mastitis symptoms (e.g., abnormal milk, or swollen, painful, or hard quarter); (3) all quarters had a milk SCC $<2 \times 10^{5}$ cells $\cdot \mathrm{mL}^{-1}$, a threshold proposed by Schukken et al. (2003) for uninfected quarters; and (4) all quarter milk samples were culture negative. From each cow, approximately $120 \mathrm{~mL}$ of peripheral blood was collected from a jugular vein in sterile vacutainer tubes containing heparin as an anticoagulant, and 1,000 $\mathrm{mL}$ of milk per quarter was collected. Afterward, blood and milk samples were 
randomized and codified (identified with letters), and the phagocytosis and intracellular ROS production were carried out without knowledge of the animal information.

\section{Milk Sample Collection}

First, the strip cup test was performed to identify the presence of clots, flakes, or other obviously abnormal secretions. Then, pre-dipping was performed, and the teats were cleaned and dried with one paper towel per teat. After discarding the first 3 milk streams, each teat was scrubbed with a cotton swab containing $70 \%$ ethanol, and single milk samples from individual mammary quarters were aseptically collected into sterile vials for bacteriological culture (approximately $3 \mathrm{~mL}$ ). Finally, quarter milk samples were collected for somatic cell counting (approximately $40 \mathrm{~mL}$ ) in vials containing bronopol (2-bromo-2-nitropane-1,3-diol) as a preserving agent, and evaluation of PMNL function (approximately $1 \mathrm{~L}$ ).

\section{Bacteriological Culture of Milk}

The bacteriological analysis was performed by culturing $10 \mu \mathrm{L}$ of each quarter milk sample on $5 \%$ sheep blood agar plates. The plates were incubated for 24 to $72 \mathrm{~h}$ at $37^{\circ} \mathrm{C}$, followed by Gram staining, observation of colony morphologies, and biochemical testing (Oliver et al., 2004). Culture-negative quarter milk samples were defined as no-growth samples and as originating from noninfected quarters.

\section{Somatic Cell Counting}

Somatic cell counting was performed using an automated, fluorescent, microscopic somatic cell counter (Somacount 300, Bentley Instruments).

\section{Isolation of Milk Cells}

The isolation of the milk cells was performed as previously described by Blagitz et al. (2013) and Souza et al. (2020). Briefly, $1 \mathrm{~L}$ of milk was diluted with $1 \mathrm{~L}$ of cold PBS ( $\mathrm{pH} 7.4 ; 1.06 \mathrm{mM} \mathrm{Na} \mathrm{HPO}_{4}, 155.17 \mathrm{NaCl}$, and $\left.2.97 \mathrm{mM} \mathrm{Na} \mathrm{HPO}_{4} \cdot 7 \mathrm{H}_{2} \mathrm{O}\right)$. After centrifugation at $1,000 \times g$ for $15 \mathrm{~min}$ at $4^{\circ} \mathrm{C}$, the cream layer and supernatant were discarded. The cell pellet was then washed once using $30 \mathrm{~mL}$ of PBS and centrifuged at $400 \times g$ for $10 \mathrm{~min}$ at $4^{\circ} \mathrm{C}$. The cells were resuspended in $1 \mathrm{~mL}$ of RPMI-1640 nutritional medium (catalog no. R7638, Sigma Aldrich) supplemented with $10 \%$ heatinactivated fetal bovine serum (Cultilab) and counted using a Neubauer chamber. Cell viability was assessed using trypan blue exclusion. The milk cells were diluted with RPMI-1640 nutritional medium (catalog no. R7638, Sigma Aldrich) supplemented with $10 \%$ heatinactivated fetal bovine serum (Cultilab) to a concentration of $2 \times 10^{6}$ viable cells $/ \mathrm{mL}$.

\section{Identification of PMNL}

A conservative gate was created using cell size (forward scatter) and cell granularity (side scatter) characteristics to identify blood PMNL using flow cytometry (Smits et al., 1997; Souza et al., 2012; Sousa Marques et al., 2021). Milk-resident PMNL were differentiated from other cells by indirect fluorescence labeling. The milk cells were incubated with a primary unlabeled $\mathrm{mAb}$ anti-bovine granulocyte (CH138A, Washington State University Monoclonal Antibody Center, Pullman) for $30 \mathrm{~min}$ on ice. Next, $1 \mathrm{~mL}$ of PBS was added to the cell suspension, which was centrifuged at $400 \times$ $g$ for $8 \mathrm{~min}$ at $4^{\circ} \mathrm{C}$. Finally, an allophycocyanin labeled secondary antibody (catalog no. M31505, goat antimouse IgM secondary antibody, ThermoFisher Scientific) was added, and the sample was incubated for 30 min on ice in the dark to visualize the bound CH138A. The milk resident PMNL were identified using flow cytometry based in cells' cytoplasmic granularities and CH138A positivity as previously described (Blagitz et al., 2015a,b; Della Libera et al., 2015). An unstained control, secondary antibody control, and single-stained samples were also prepared as compensation controls. FlowJo software (Tree Star Inc.) was used to analyze the data.

\section{Intracellular ROS Production}

Intracellular ROS production was evaluated using $2^{\prime}, 7^{\prime}$-dichlorofluorescein diacetate by flow cytometry, as previously described (Blagitz et al., 2017; Santos et al., 2017; Souza et al., 2020) with some minor modifications. For the evaluation of intracellular ROS production, PMNL were stimulated with distinct live nonlabeled staphylococci. First, $100 \mu \mathrm{L}$ of blood samples were hypotonic, and erythrocytes in blood samples were lysed by adding $1,000 \mu \mathrm{L}$ of $0.2 \% \mathrm{NaCl}$ for $20 \mathrm{~s}$; then, isotonicity was restored by adding $1,000 \mu \mathrm{L}$ of $1.6 \% \mathrm{NaCl}$. Briefly, blood PMNL (approximate ratio of 25 bacteria per PMNL) or $2 \times 10^{5}$ viable milk cells (ratio 25 bacteria per milk cell) were incubated with nonlabeled staphylococci for $30 \mathrm{~min}$ at $37^{\circ} \mathrm{C}$. The basal unstimulated (without bacteria) production of ROS by PMNL was also measured. Finally, the milk resident PMNL were identified using $\mathrm{mAb}$, as described above. 
Here, 20,000 cells, excluding most of the debris, were examined per sample. The sample readings were carried out using a FACSCalibur flow cytometer (Becton Dickinson Immunocytometry Systems) with argon (488 $\mathrm{nm}$ excitation) and diode (635 $\mathrm{nm}$ excitation) lasers. FlowJo software (Tree Star Inc.) was used to analyze the data. The results were corrected for autofluorescence content using nonlabeled milk cells from the same mammary quarter milk samples and blood samples.

Data are presented as percentage of PMNL that produced ROS (percentage of stained cells) and geometric mean fluorescence intensity (GMFI). The latter parameter provides an accurate measurement of the brightness of stained cells. The GMFI values of ROS production were determined among PMNL that produced ROS (positive cells), indicating the intensity of ROS production per PMNL.

\section{Phagocytosis Assay}

The phagocytosis assay was performed using flow cytometry of live CFSE-labeled staphylococci, as previously described (Della Libera et al., 2015; Blagitz et al., 2017; Souza et al., 2020). For blood samples, the whole blood assay was carried out. For the phagocytosis assay using milk cells, both opsonized and nonopsonized bacteria were used. First, $100 \mu \mathrm{L}$ of blood samples were hypotonic and lysis of erythrocytes in blood samples was performed by adding $1,000 \mu \mathrm{L}$ of $0.2 \% \mathrm{NaCl}$ for 20 $\mathrm{s}$; then, isotonicity was restored by adding $1,000 \mu \mathrm{L}$ of $1.6 \% \mathrm{NaCl}$. Briefly, blood PMNL (approximate ratio of 25 bacteria per PMNL) or $2 \times 10^{5}$ viable milk cells (ratio of 25 bacteria per milk cell) were incubated with CFSE-labeled staphylococci for $30 \mathrm{~min}$ at $37^{\circ} \mathrm{C}$. Subsequently, $2 \mathrm{~mL}$ of $3 \mathrm{~m} M$ EDTA was added to exclude adherent bacteria to the leukocyte membrane that could be erroneously identified as ingested (Batista et al., 2018), and then samples were centrifuged at $400 \times g$ for 10 min at $4^{\circ} \mathrm{C}$. Finally, the milk resident PMNL were identified using $\mathrm{mAb}$, as described above. Here, 20,000 cells, excluding most of the debris, were examined per sample. The sample readings were carried out using a FACSCalibur flow cytometer (Becton Dickinson Immunocytometry Systems) with argon (488 nm excitation) and diode (635 nm excitation) lasers. FlowJo software (Tree Star Inc.) was used to analyze the data. The results were corrected for autofluorescence content using nonlabeled milk cells from the same mammary quarter milk samples and blood samples.

Data are presented as a percentage of PMNL that phagocytosed CFSE-labeled bacteria (percentage of stained cells), and GMFI. The latter parameter provides an accurate measurement of the brightness of stained cells. The GMFI of phagocytosis were determined among PMNL that phagocytosed bacteria (positive cells), indicating the number of bacteria phagocytosed per PMNL.

\section{Statistical Analyses}

All data were entered in an electronic spreadsheet program (Excel 2016, Microsoft Corp.) and were checked for outliers' values. Because the conventional ways of transformation (e.g., $\log _{10}$, ln, inverse, square root, quadratic) were not sufficient to obtain normally distributed outcome variables, a 2-step approach as described by Templeton (2011) was applied on all 8 outcome variables (percentage of phagocytosis by blood PMNL, intensity of phagocytosis by blood PMNL, percentage of phagocytosis by milk PMNL, intensity of phagocytosis by milk PMNL, percentage of intracellular ROS production by blood PMNL, intensity of intracellular ROS production by blood PMNL, percentage of intracellular ROS production by milk PMNL, and intensity of intracellular ROS production by milk PMNL). The first step involved transforming the variable into a percentile rank, which resulted in uniformly distributed probabilities. The second step applied the inverse-normal transformation to the results of the first step to form a variable consisting of normally distributed $z$-scores. The mean and standard deviation of the original variable were retained to improve the interpretation of the results.

First, 4 independent samples $t$-tests were run to test whether opsonization or parity was significantly associated with the following outcome variables: percentage of phagocytizing blood PMNL, percentage of phagocytizing milk resident PMNL, GMFI of the phagocytizing blood, and GMFI of the phagocytizing milk resident PMNL (SAS PROC GLM; version 9.4; SAS Institute Inc.). Because opsonization and parity were not significantly associated with any of the outcome variables, the subsequent analyses were only carried out on the nonopsonized bacteria, and we did not consider parity.

Second, 3 times 8 independent $t$-tests or ANOVA were run to evaluate the association between different strata of staphylococci and the phagocytotic capacity and oxidative burst activity of the blood and milk resident PMNL, respectively. The 8 different outcome variables were the percentage of phagocytizing blood and milk resident PMNL, respectively, the GMFI of the phagocytizing blood and milk resident PMNL, respectively, the percentage of ROS-producing blood and milk resident PMNL, respectively, and the GMFI of the intracellular ROS production of blood and milk resident PMNL. The 3 different strata of staphylo- 
cocci were "Staphylococcal species group" (2 levels; 1 = NAS; 2 = Staphylococcus aureus), "Staphylococcal species" (4 levels; $1=$ Staphylococcus aureus; $2=S$. fleurettii; $3=S$. haemolyticus; $4=S$. chromogenes $)$, and "Staphylococcal species per niche" (8 levels, $1=S$. chromogenes from TA; $2=S$. chromogenes from milk; $3=S$. haemolyticus from TA; $4=S$. haemolyticus from milk; $5=S$. fleurettii from milk; $6=S$. fleurettii from environment; $7=$ Staphylococcus aureus from nose; 8 $=S$. aureus from milk). In all models, a Tukey's correction was used to correct for multiple comparisons. Significance was assessed at $P \leq 0.05$.

\section{RESULTS}

\section{Blood and Milk Phagocytosis}

Phagocytosis by both blood and milk PMNL did not differ between $S$. aureus and NAS as a group (Figure 1, I), although some interesting variations were observed between species in their ability to resist phagocytosis. Staphylococcus haemolyticus was more often phagocytosed (GMFI) by blood PMNL than $S$. aureus, $S$. fleurettii, and S. chromogenes (Figure 2, I), whereas the latter was less likely to be phagocytosed by blood (percentage and GMFI) than S. haemolyticus and S. fleurettii (Figure 2, I). Furthermore, S. chromogenes was less phagocytosed (GMFI) by milk resident PMNL than S. haemolyticus (Figure 2, I). No statistical differences were found in resistance to phagocytosis by blood and milk PMNL among the isolates originating from distinct niches within the staphylococci species, although some numerical differences were seen between $S$. chromogenes originating from milk and TA and between S. fleurettii originating from milk and the environment, which may indicate some biological relevance (Figure 3, I).

\section{Intracellular ROS Production in Blood and Milk PMNL}

Overall, the staphylococci (combining S. aureus and NAS) did not inhibit intracellular ROS production by blood and milk resident PMNL as compared with the basal values (Figure 1, II). Still, NAS induced less ROS (GMFI) by milk PMNL than $S$. aureus which was not true for blood PMNL (Figure 1, II). Also, species-level differences were observed in the intensity of ROS production (Figure 2, II): S. chromogenes induced more ROS by blood PMNL (percentage) than S. fleurettii and $S$. haemolyticus and as much as $S$. aureus. On the other hand, S. chromogenes induced less ROS production by milk PMNL (GMFI) than S. aureus. Within-species differences were less evident (Figure 3, II), although the intensity of ROS production by blood PMNL was numerically greater when in contact with $S$. chromogenes isolated from TA than from milk.

\section{DISCUSSION}

It is well known that $S$. aureus has developed several mechanisms to evade host immune response, and this bacterium is recognized as a formidable neutrophil foe capable of challenging the efficacy of this professional phagocyte (Thammavongssa et al., 2015; Guerra et al., 2017). The ability of mastitis-associated $S$. aureus to resist phagocytosis and to avoid bactericidal killing has been studied before (Sutra et al., 1990; Aarestrup et al., 1994; Barrio et al., 2000), although to the best of our knowledge, none of the studies have assessed the ability of $S$. aureus isolated from extra-mammary niches to do so and has compared them with milkassociated $S$. aureus to resist phagocytosis and inhibit respiratory burst activity by blood and milk resident PMNL in dairy cows. Furthermore, although some previous studies have characterized the ability of human NAS to resist phagocytosis and bactericidal killing by phagocytes (Schutze et al., 1991; Spiliopoulou et al., 2012), no studies are available that have investigated the ability of bovine-associated NAS to resist phagocytosis and bactericidal killing mechanisms by blood and milk resident PMNL in dairy cows. The resistance to phagocytosis by bovine-associated NAS species was just investigated previously using a murine macrophage cell line (Åvall-Jääskeläinen et al., 2013).

In the present study, no differences in the phagocytic capacity of blood and milk PMNL between NAS (as a group) and $S$. aureus were found. Yet, at the NAS species level, the so-called milk-adapted $S$. chromogenes better resisted PMNL phagocytosis than other environmental (i.e., S. fleurettii) and opportunistic (i.e., $S$. haemolyticus) NAS species. In this regard, Naushad et al. (2019) showed that each additional host immune evasion and toxin gene among NAS species increased the odds of causing high SCC or clinical mastitis. Altogether, these findings suggest that the evasion of PMNL phagocytosis by $S$. chromogenes may support at least in part why this species is of one the most prevalent NAS isolated from milk samples, is more likely to cause persistent IMI (Supré et al., 2011; Fry et al., 2014; Valckenier et al., 2020), and induces the highest SCC values among NAS (Supré et al., 2011; Valckenier et al., 2020). In this regard, the S. chromogenes strains (one originated from milk and one originated from teat apex) also persisted for a substantially longer time in the mammary glands of both mice and dairy cows compared with the environmental $S$. fleurettii strain after 


\section{I) Phagocytosis}

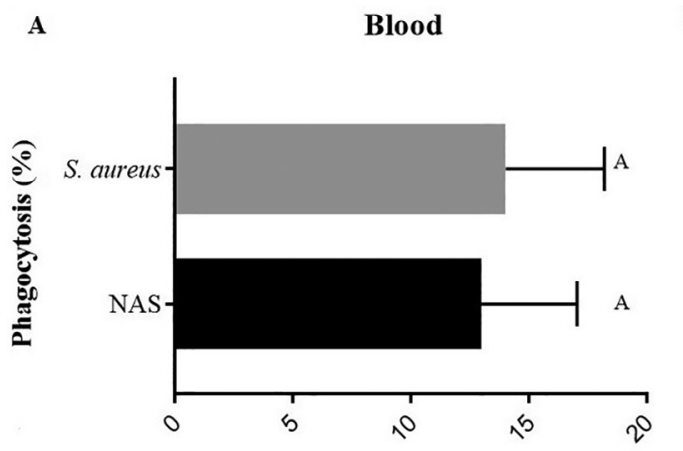

Blood

C

Milk
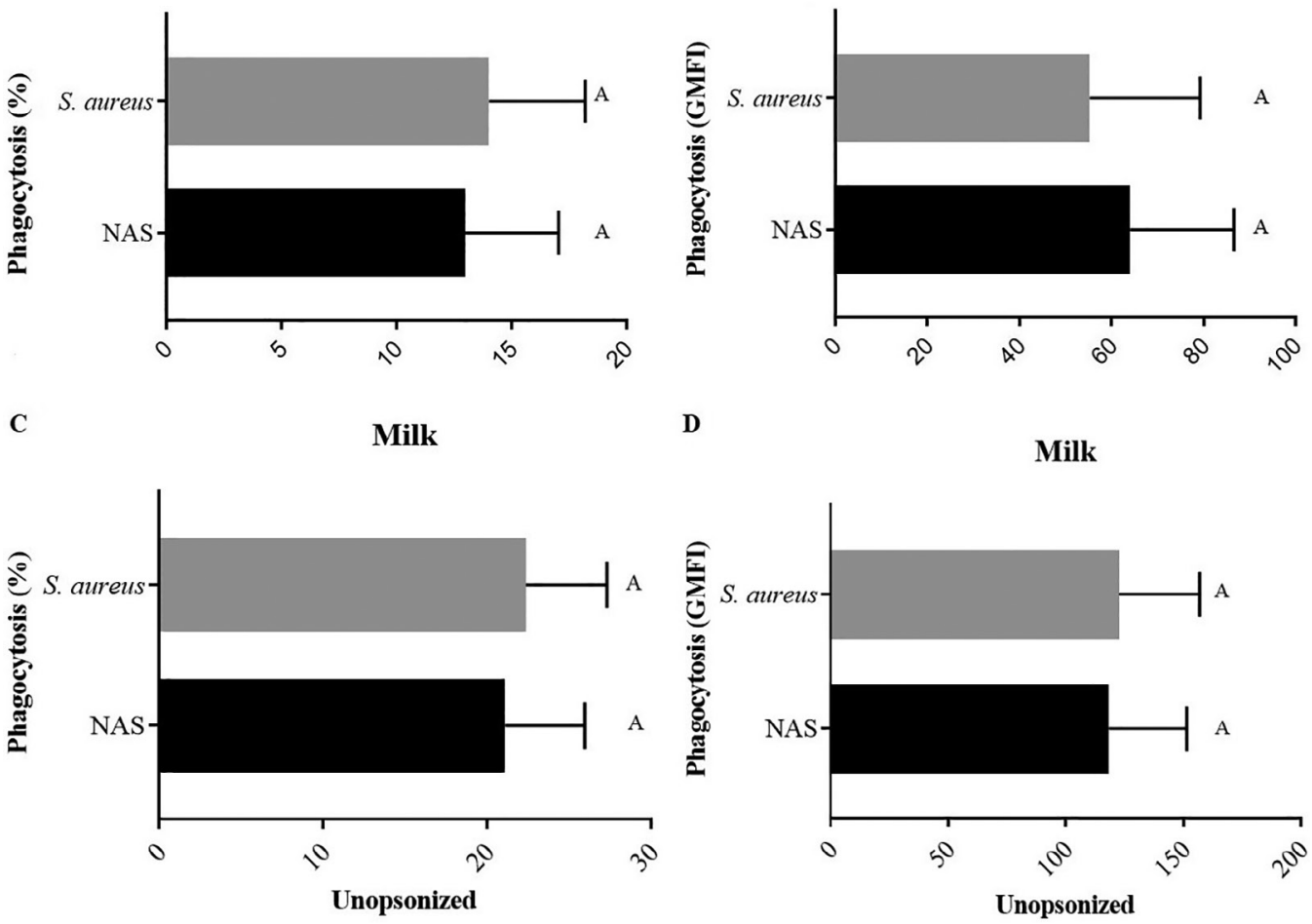

\section{II) Intracellular Reactive Oxygen Species Production}

A

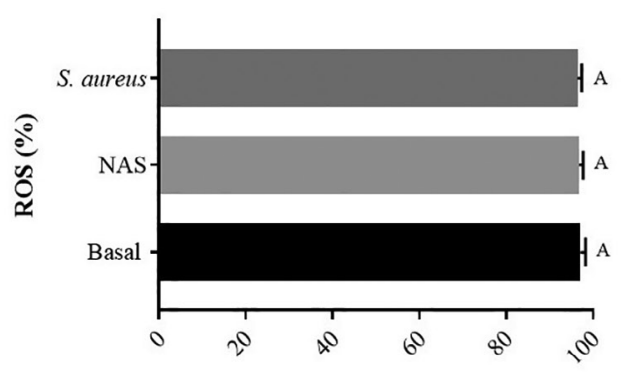

C

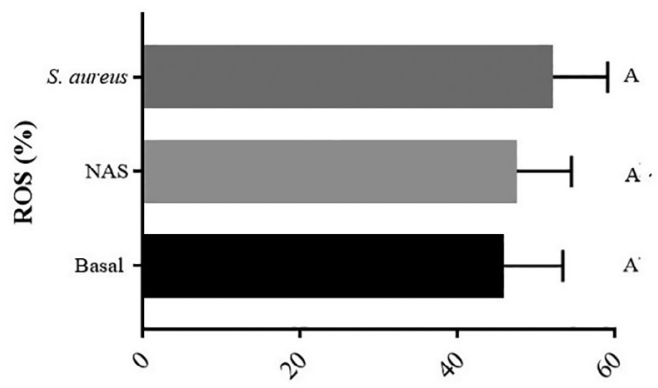

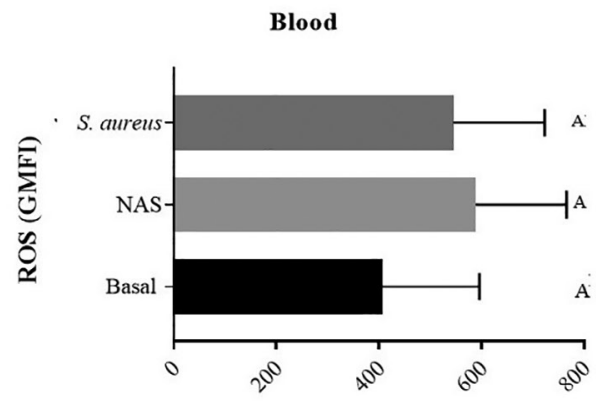

D

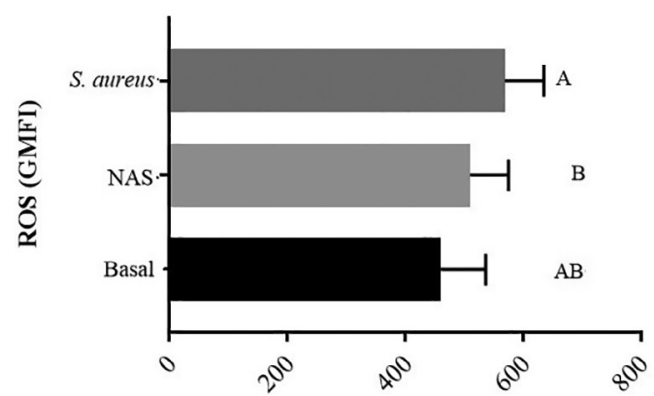

Figure 1. Least squares means $( \pm \mathrm{SEM})$ of the percentage $(\%)$ and geometric mean fluorescence intensity (GMFI) of blood and milk polymorphonuclear neutrophil leukocyte phagocytosis (part I) and intracellular reactive oxygen species (ROS) production (part II) triggered by the NAS as a group combined versus Staphylococcus aureus. Different letters indicate significant differences among groups $(P \leq 0.05)$. 


\section{I) Phagocytosis}

$\mathbf{A}$

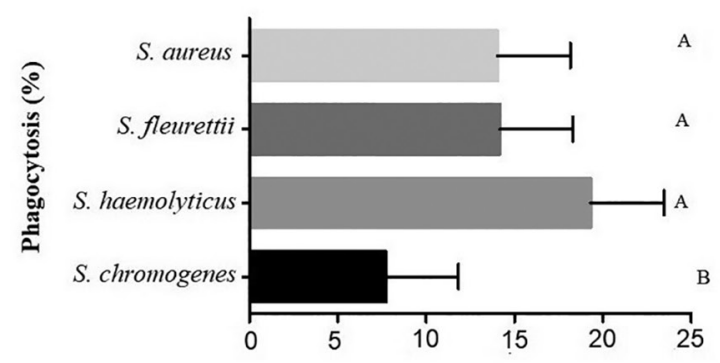

C

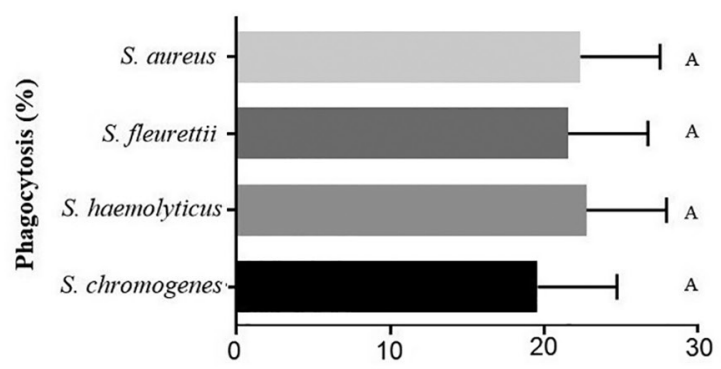

Unopsonized
B

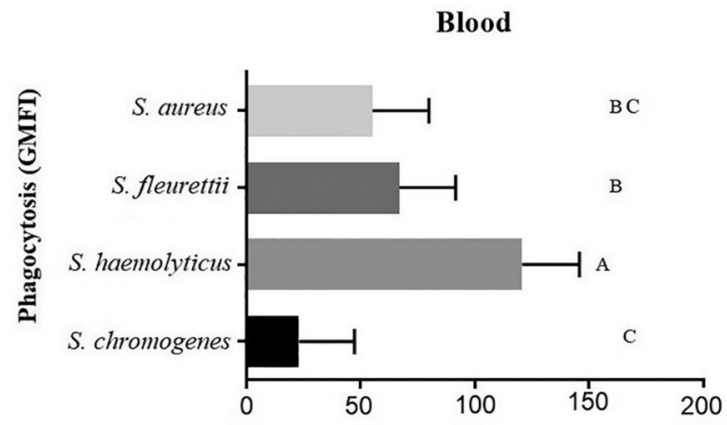

D

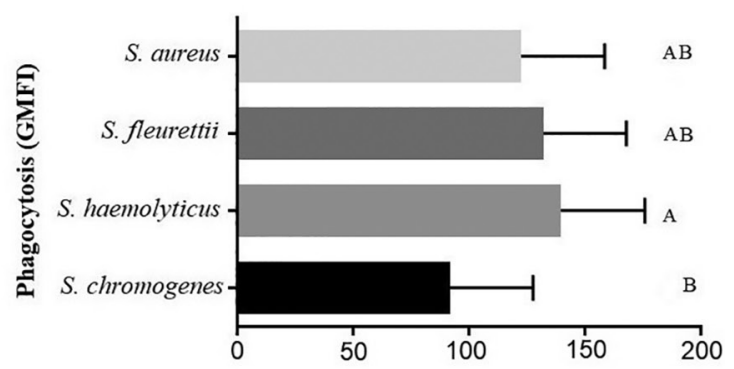

Unopsonized

\section{II) Intracellular Reactive Oxygen Species Production}

A

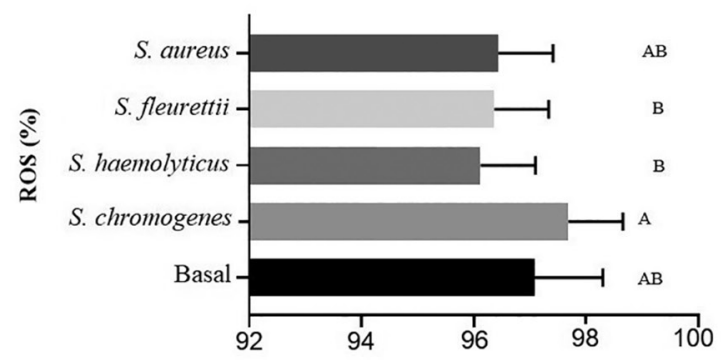

C

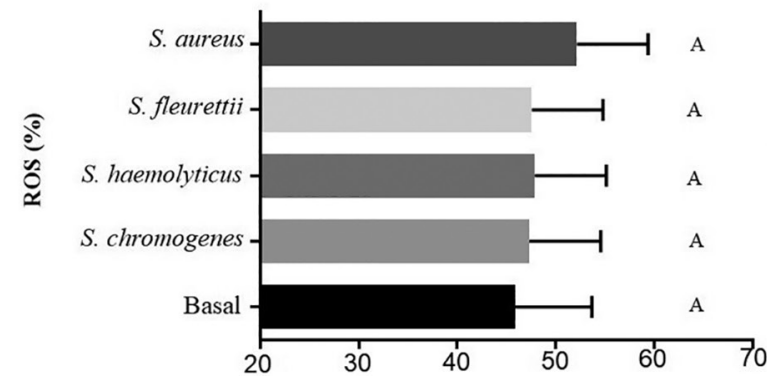

B

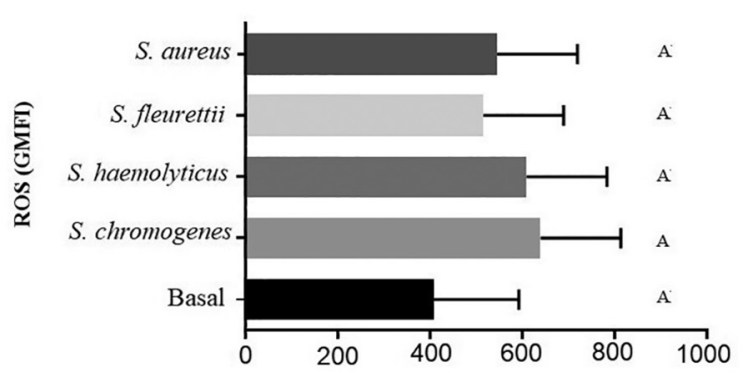

D

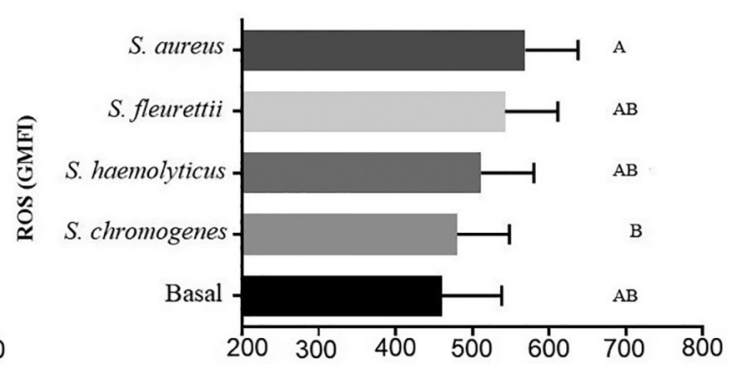

Figure 2. Least squares means $( \pm$ SEM) of the percentage $(\%)$ and geometric mean fluorescence intensity (GMFI) of phagocytosis (part I) and intracellular reactive oxygen species (ROS) production (part II) triggered by distinct staphylococcal species by blood and milk polymorphonuclear neutrophil leukocytes. Different letters indicate significant differences among groups $(P \leq 0.05)$. 


\section{I) Phagocytosis}
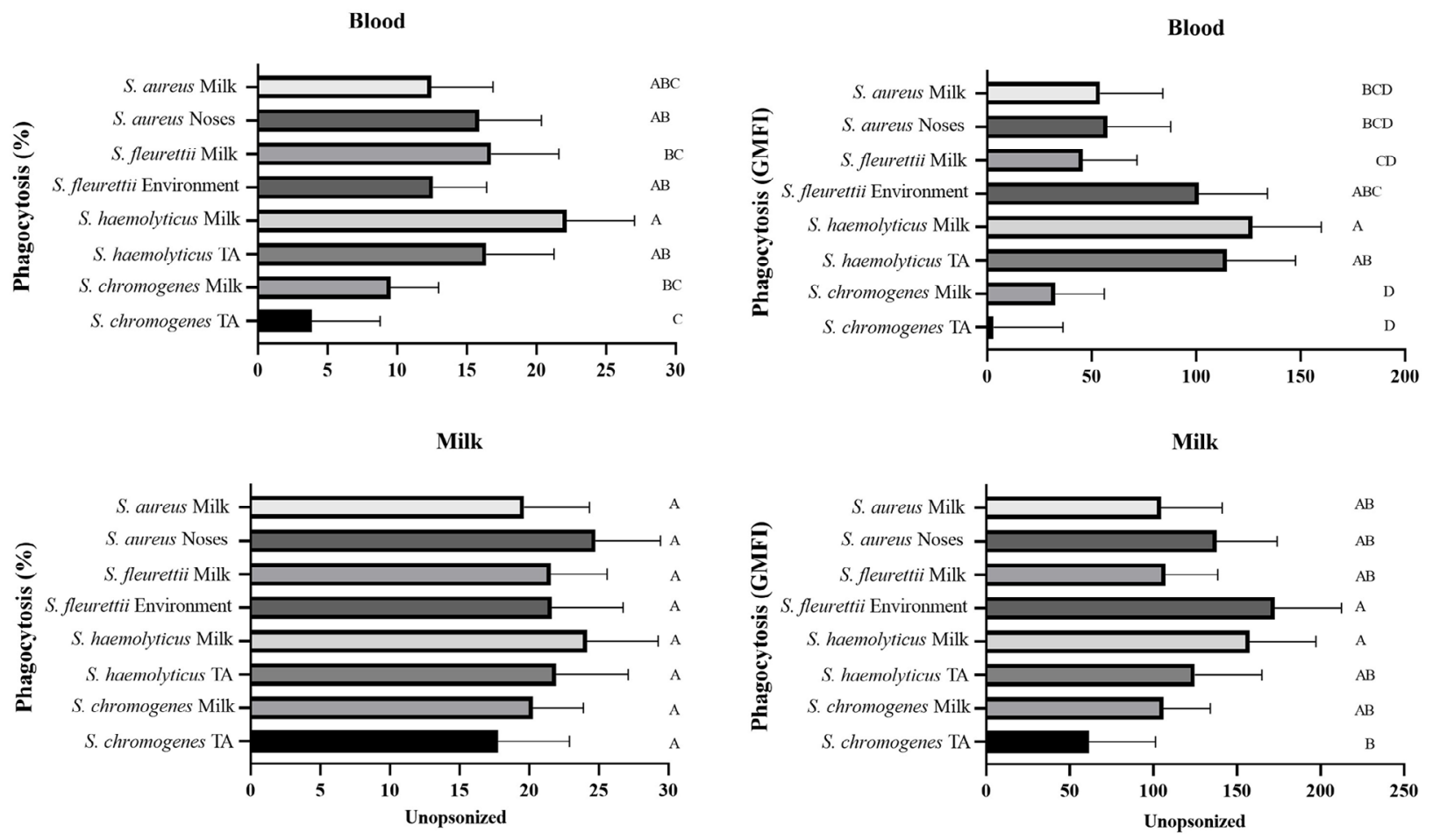

II) Intracellular Reactive Oxygen Species Production
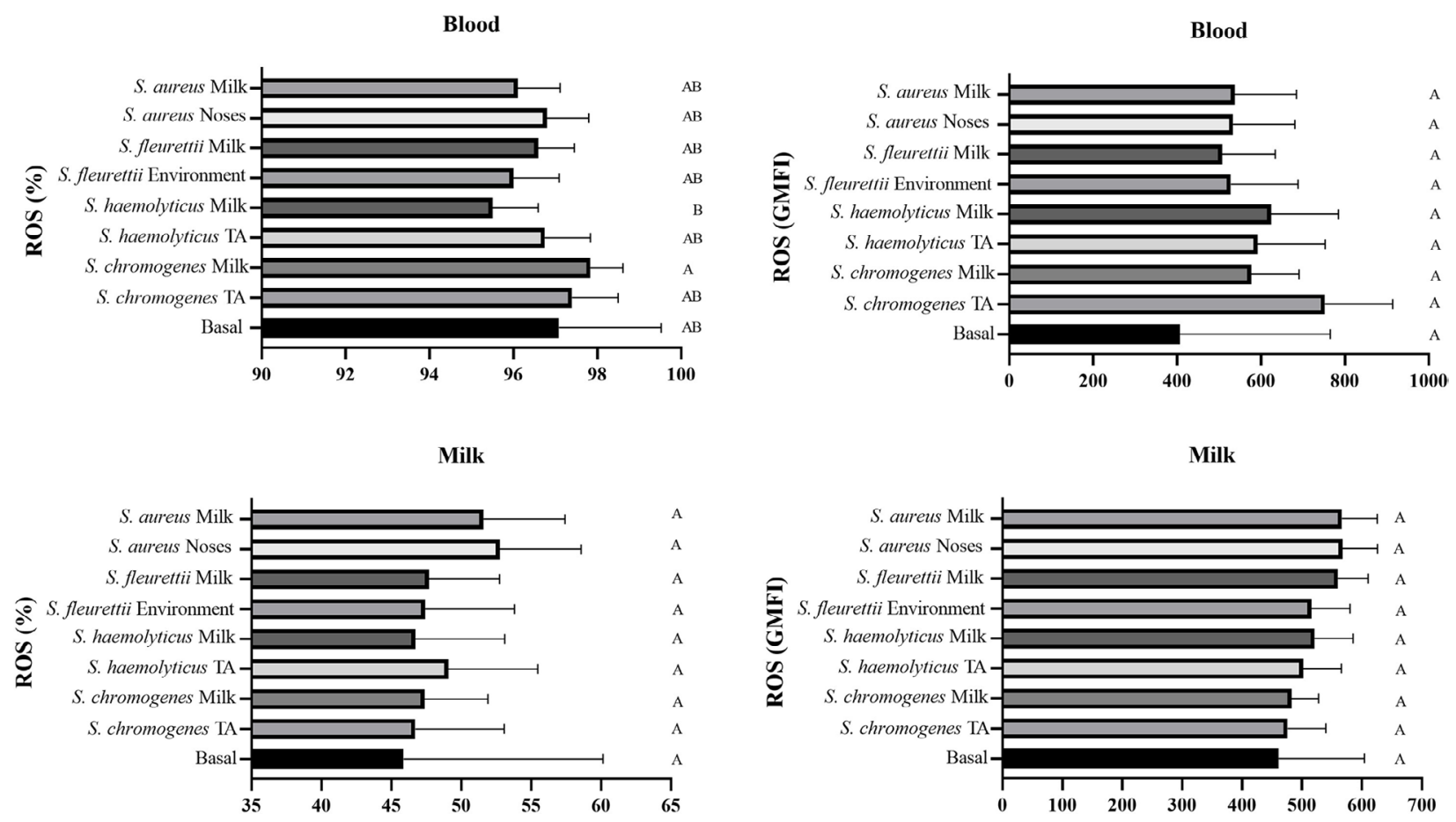

Figure 3. Least squares means $( \pm$ SEM) of the percentage $(\%)$ and geometric mean fluorescence intensity (GMFI) of phagocytosis (part I) and the intracellular reactive oxygen species (ROS) production (part II) triggered by distinct bovine-associated staphylococcal species isolated from milk samples and extramammary niches by blood and milk polymorphonuclear neutrophil leukocytes. Different letters indicate significant differences among groups $(P \leq 0.05)$. TA $=$ teat apices. 
experimental challenges (Breyne et al., 2015; Piccart et al., 2016). As a result, we assume that $S$. chromogenes, like $S$. aureus (Foster, 2005), developed means to evade PMNL phagocytosis, although the exact underlying mechanisms are still unknown.

Despite the huge variation within each niche, the lower phagocytosis rates (both in the percentage and GMFI) in case of $S$. chromogenes originating from milk and TA is quite intriguing. In our previous studies, both $S$. chromogenes isolated from TA and milk persisted into the bovine mammary gland (Piccart et al., 2016), although $S$. chromogenes isolated from TA had a substantial lower capability to adhere and internalize into bovine mammary epithelial cells (Souza et al., 2016b), which could explain, at least in part, the lower bacterial shedding of $S$. chromogenes TA (Piccart et al., 2016). Based on the findings in the current study, we hypothesize that the resistance to phagocytosis might indicate a vital evasion strategy of $S$. chromogenes isolated from TA to persist into bovine mammary gland despite their inability to adhere and internalize into mammary epithelial cells.

Mastitis-causing pathogens are subjected to pressures exerted by the mammary immune response, absence of nutrients (e.g., iron), and intermittent antibiotic exposure at high concentrations, which could altogether constitute an environmental challenge that drives evolutionary selective pressure for adaptive coevolution in this ecological niche. Also, bacteria present in the different habitats aside from the mammary gland (e.g., teat apex and noses as in our study) are subjected to distinct pressures such as microbiotal competition, some immune system control, and intermittent antibiotic exposure at low concentrations (Giulieri et al., 2018). Thereupon, it is reasonable to suppose that milk-adapted staphylococci isolates may better evade the immune response mechanism favoring invasion and persistency. Nonetheless, the only finding that supports the idea is a more pronounced resistance to phagocytosis of the so-called milk-adapted species (i.e., S. chromogenes) than other so-called opportunistic (i.e., S. haemolyticus) and environmental (i.e., S. fleurettii) NAS species, although the intra-species outcomes did not support this hypothesis.

Furthermore, regarding the inhibition of intracellular ROS production by all staphylococcal species, none of them inhibited intracellular ROS production as all of them led to greater or similar ROS production levels than the unstimulated controls. Nevertheless, some slight differences in the respiratory burst activity were observed among the staphylococcal species, which could be related to their ability to trigger inflammation. In that respect, $S$. aureus was associated with a greater intracellular ROS production by milk resident PMNL, whereas a greater ROS production by blood PMNL was observed upon $S$. chromogenes stimulation, potentially implying a greater ROS production by freshly migrated blood PMNL into the mammary gland. Also, one should take into account that ROS levels can dictate a variety of cellular signaling pathways, which mediate pathological processes including inflammation (DupréCrochet et al., 2013) that were not measured in this study.

No significant improvement of milk PMNL phagocytosis could be observed using heat-inactivated autologous blood bovine serum. The latter could be explained at least in part by staphylococcal virulence factors that inhibit opsonic phagocytosis (Barrio et al., 2000; Foster, 2005; Rooijakkers et al., 2005) and the absence of specific antibodies against the targeted strains. Finally, we observed that parity did not affect PMNL function in mid-lactating dairy cows. Under other circumstances, Mehrzad et al. (2009) reported that the phagocytosis of $S$. aureus and killing activity by PMNL in primiparous cows was substantially greater than in multiparous cows during early lactation. In this setting, we assume that the alterations on PMNL functions in multiparous cows are not sustained during the whole lactation, although a further longitudinal study is needed before definite conclusions can be drawn.

We should acknowledge that the PMNL activities in the current study were carried out in the context where they could be modified by other cell types as all blood and milk cells were present in the functional assays. Similar to our study, several studies have used all blood (so-called whole blood assay) and milk cells in their assays to investigate activities of a particular cell type (Blagitz et al., 2013; Della Libera et al., 2015; Souza et al., 2020). In numerous studies, similar patterns as those obtained with fractional PMNL were observed. Also, so-called whole blood assays have long been regarded as a simple, reproducible, biologically and clinically relevant assay that allow us to assess immune functions ex vivo (Pattanapanyasat et al., 2007; Gupta-Wright et al., 2017; Reiné et al., 2020).

\section{CONCLUSIONS}

We hypothesized that the ecological niche (milk versus nonmilk) affected the phagocytosis evasion mechanisms of the staphylococci toward PMNL, yet our results do not support this hypothesis. Apart from the finding that $S$. chromogenes (a so-called milk-adapted NAS species) better resisted phagocytosis by PMNL than the so-called environmental (i.e., S. fleurettii) and opportunistic (i.e., S. haemolyticus) NAS species, no 
other differences between niches were observed. None of the staphylococci including $S$. aureus inhibited intracellular ROS production by PMNL. Nevertheless, some slight differences in the respiratory burst activity existed between staphylococcal species, suggesting that some can most probably induce a greater inflammation than others.

\section{ACKNOWLEDGMENTS}

The authors are grateful for the financial support of the São Paulo State Research Foundation (FAPESP; project no. 2015/16871-6; Brazil) and Coordinator for the Improvement of Higher Education Personnel (CAPES; Brazil). AMMPDL and MBH thank the CNPq (Brazil) for their fellowships. RMS thanks CAPES for his fellowship. FNS (process no. 2014/23189-4 and 2017/07921-5), PCCM (process no. 2016/06297-3), and JAF (process no. 2018/03685-8) thank FAPESP for their fellowships. The funders had no role in study design, data collection and analysis, decision to publish, or preparation of the manuscript. The data on which the conclusions of the manuscript rely are presented in the main paper and additional files. The authors have not stated any conflicts of interest.

\section{REFERENCES}

Aarestrup, F. M., N. L. Scott, and L. M. Sordillo. 1994. Ability of Staphylococcus aureus coagulase genotypes to resist neutrophil bactericidal activity and phagocytosis. Infect. Immun. 62:56795682. https://doi.org/10.1128/iai.62.12.5679-5682.1994.

Adkins, P. R. F., S. Dufour, J. N. Spain, M. J. Calcutt, T. J. Reilly, G. C. Stewart, and J. R. Middleton. 2018. Molecular characterization of non-aureus Staphylococcus spp. from heifer intramammary infections. J. Dairy Sci. 101:5388-5403. https://doi.org/10.3168/ jds.2017-13910.

Åvall-Jääskeläinen, S., J. Koort, H. Simojoki, and S. Taponen. 2013. Bovine-associated CNS species resist phagocytosis differently. BMC Vet. Res. 9:227. https://doi.org/10.1186/1746-6148-9-227.

Barrio, B., F. Vangroenweghe, H. Dosogne, and C. Burvenich. 2000. Decreased neutrophil bactericidal activity during phagocytosis of a slime-producing Staphylococcus aureus strain. Vet. Res. 31:603609. https://doi.org/10.1051/vetres:2000143.

Batista, C. F., F. N. Souza, K. R. Santos, E. M. Ramos Sanchez, L. C. Reis, H. G. Bertagnon, M. G. Blagitz, R. C. Gomes, A. P. Lage, M. B. Heinemann, and A. M. M. P. Della Libera. 2018. R-Phycoerythrin-labeled Mannheimia haemolytica for the simultaneous measurement of phagocytosis and intracellular reactive oxygen species production in bovine blood and bronchoalveolar lavage cells. Vet. Immunol. Immunopathol. 196:53-59. https://doi .org/10.1016/j.vetimm.2017.12.004.

Blagitz, M. G., F. N. Souza, C. F. Batista, L. F. Azevedo, N. R. Benites, P. A. Melville, S. A. Diniz, M. X. Silva, J. P. Haddad, M. B. Heinnemann, M. M. O. P. Cerqueira, and A. M. M. P. Della Libera. 2015a. The neutrophil function and lymphocyte profile of milk from bovine mammary glands infected with Streptococcus dysgalactiae. J. Dairy Res. 82:460-469. https://doi.org/10.1017/ S0022029915000308.

Blagitz, M. G., F. N. Souza, C. F. Batista, L. F. F. Azevedo, E. M. R. Sanchez, S. A. Diniz, M. X. Silva, J. P. Haddad, and A. M. M. P. Della Libera. 2017. Immunological implications of bovine leuke- mia virus infection. Res. Vet. Sci. 114:109-116. https://doi.org/10 $.1016 /$ j.rvsc. 2017.03.012.

Blagitz, M. G., F. N. Souza, C. F. Batista, S. A. Diniz, L. F. Azevedo, M. X. Silva, J. P. Haddad, M. B. Heinemann, M. M. O. P. Cerqueira, and A. M. M. P. Della Libera. 2015b. Flow cytometric analysis: interdependence of healthy and infected udder quarters. J. Dairy Sci. 98:2401-2408. https://doi.org/10.3168/jds.2014-8727.

Blagitz, M. G., F. N. Souza, B. P. Santos, C. F. Batista, A. C. Parra, L. F. F. Azevedo, P. A. Melville, N. R. Benites, and A. M. M. P. Della Libera. 2013. Function of milk polymorphonuclear neutrophils leukocytes in bovine mammary glands infected with Corynebacterium bovis. J. Dairy Sci. 96:3750-3757. https://doi.org/10 $.3168 /$ jds.2012-6370.

Breyne, K., S. De Vliegher, A. De Visscher, S. Piepers, and E. Meyer. 2015. Technical note: A pilot study using a mouse mastitis model to study differences between bovine associated coagulase-negative staphylococci. J. Dairy Sci. 98:1090-1100. https://doi.org/10 .3168/jds.2014-8699.

Cunha, A. F., H. M. Andrade, F. N. Souza, L. C. Fialho Júnior, D. L. S. O. Rosa, E. M. R. Ramos Sanchez, M. Gidlund, H. Goto, M. A. V. P. Brito, A. S. Guimarães, A. P. Lage, L. C. Reis, A. M. M. P. Della Libera, M. B. Heinemann, and M. M. O. P. Cerqueira. 2020. Comparison of antibody repertories against Staphylococcus aureus in healthy and infected dairy cows with distinct mastitis history and vaccinated with a polyvalent mastitis vaccine. J. Dairy Sci. 103:4588-4605. https://doi.org/10.3168/jds.2019-17084.

Della Libera, A., F. de Souza, C. Batista, B. Santos, L. de Azevedo, E. Sanchez, S. Diniz, M. Silva, J. Haddad, and M. Blagitz. 2015 Effects of bovine leukemia virus infection on milk neutrophil function and milk lymphocyte profile. Vet. Res. 46:2. https://doi.org/ 10.1186/s13567-014-0125-4.

de Souza, F., R. Souza, C. Batista, S. Piepers, A. De Visscher, K. Santos, P. Molinari, J. Ferronatto, A. Cunha, M. Blagitz, G. Silva, F. Renno, M. Cerqueira, M. Heinemann, S. de Vliegher, and A. Della Libera. 2021. Supplemental Fig. 1. Souza JDS 2021. jpg. figshare. Figure. https://doi.org/https://doi.org/10.6084/m9 .figshare.14877834.v1.

De Visscher, A., S. Piepers, F. Haesebrouck, and S. De Vliegher. 2016. Teat Apex colonization with coagulase-negative Staphylococcus species before parturition: Distribution and species-specific risk factors. J. Dairy Sci. 99:1427-1439. https://doi.org/10.3168/jds .2015-10326.

De Visscher, A., K. Supré, F. Haesebrouck, R. N. Zadoks, V. Piessens, E. Van Coillie, and S. Piepers. 2014. Further evidence for the existence of environmental and host-associated species of coagulasenegative staphylococci in dairy cattle. Vet. Microbiol. 172:466-474. https://doi.org/10.1016/j.vetmic.2014.06.011.

Dupré-Crochet, S., M. Erard, and O. Nüße. 2013. ROS production in phagocytes: Why, when and where? J. Leukoc. Biol. 94:657-670. https://doi.org/10.1189/jlb.1012544.

Foster, T. J. 2005. Immune evasion by staphylococci. Nat. Rev. Microbiol. 3:948-958. https://doi.org/10.1038/nrmicro1289.

Fry, P. R., J. R. Middleton, S. Dufour, J. Perry, D. Scholl, and I. Dohoo. 2014. Association of coagulase-negative staphylococcal species, mammary quarter milk somatic cell count, and persistence of intramammary infection in dairy cattle. J. Dairy Sci. 97:48764885. https://doi.org/10.3168/jds.2013-7657.

Giulieri, S. G., S. L. Baines, R. Guerillot, T. Seemann, A. Gonçalves da Silva, M. Schultz, R. C. Massey, N. E. Holmes, T. P. Stinear, and B. P. Howden. 2018. Genomic exploration of sequential clinical isolates reveals a distinctive molecular signature of persistent Staphylococcus aureus bacteraemia. Genome Med. 10:65. https:// doi.org/10.1186/s13073-018-0574-x.

Guerra, F. E., T. R. Borgogna, D. M. Patel, E. W. Sward, and J. M. Voyich. 2017. Epic immune battle of history: Neutrophils vs. Staphylococcus aureus. Front. Cell. Infect. Microbiol. 7:286. https: //doi.org/10.3389/fcimb.2017.00286.

Gupta-Wright, A., D. Tembo, K. C. Jambo, E. Chimbayo, L. Mvaya, S. Caldwell, D. G. Russell, and H. C. Mwandumba. 2017. Functional analysis of phagocyte activity in whole blood from HIV/ Tuberculosis-infected individuals using a novel flow cytometry- 
based assay. Front. Immunol. 8:1222. https://doi.org/10.3389/ fimmu.2017.01222.

Halasa, T., M. Nielen, R. B. M. Huirne, and H. Hogeveen. 2009. Stochastic bio-economic model of bovine intramammary infection. Livest. Sci. 124:295-305. https://doi.org/10.1016/j.livsci.2009.02 .019 .

Horn, J., K. Stelzner, T. Rudel, and M. Fraunholz. 2018. Inside job: Staphylococcus aureus host-pathogen interactions. Int. J. Med. Microbiol. 308:607-624. https://doi.org/10.1016/j.ijmm.2017.11.009.

Leuenberger, A., C. Sartori, R. Boss, G. Resch, F. Oechslin, A. Steiner, P. Moreillon, and H. U. Graber. 2019. Genotypes of Staphylococcus aureus: On-farm epidemiology and the consequences for prevention of intramammary infections. J. Dairy Sci. 102:3295-3309. https:// doi.org/10.3168/jds.2018-15181.

Mehrzad, J., L. Duchateau, and C. Burvenich. 2009. Phagocytic and bactericidal activity of blood and milk-resident neutrophils against Staphylococcus aureus in primiparous and multiparous cows. Vet. Microbiol. 134:106-112. https://doi.org/10.1016/j.vetmic.2008.09 .001 .

Moura, G. S., W. A. Gebreyes, M. F. S. Marques, D. T. Stipp, F. N. Souza, L. B. Da Costa, and C. J. B. Oliveira. 2018. Short Communication: Occurrence of methicillin-resistant Staphylococcus aureus and coagulase-negative staphylococci in dairy goats herds in Ohio, United States. J. Dairy Sci. 101:7804-7807. https://doi.org/ 10.3168/jds.2017-13361.

Naushad, S., S. Ali Naqvi, D. Nobrega, C. Luby, J. P. Kastelic, H. W. Barkema, and J. De Buck. 2019. Comprehensive virulence gene profiling of bovine non-aureus staphylococci based on whole-genome sequencing data. mSystems 4:e00098-18. https://doi.org/10 $.1128 /$ mSystems.00098-18.

Oliver, S. P., R. N. González, J. S. Hogan, B. M. Jayarao, and W E. Owens. 2004. Microbiological procedures for the diagnosis of bovine udder infection and determination of milk quality. National Mastitis Council.

Paape, M. J., D. D. Bannermann, X. Zhao, and J. W. Lee. 2003. The bovine neutrophil: Structure and function in blood and milk. Vet. Res. 34:597-627. https://doi.org/10.1051/vetres:2003024.

Pattanapanyasat, K., K. Sukapirom, K. Tachavanich, and S. Kaewmoon. 2007. Flow cytometric quantitation of opsonophagocytosis and intracellular killing of Candida albicans using a whole blood microassay. Cytometry A 71:1027-1033. https://doi.org/10.1002/ cyto.a.20475

Piccart, K., J. Verbeke, A. De Visscher, S. Piepers, F. Haesebrouck, and S. De Vliegher. 2016. Local host response following an intramammary challenge with Staphylococcus fleurettii and different strains of Staphylococcus chromogenes in dairy heifers. Vet. Res. 47:56. https://doi.org/10.1186/s13567-016-0338-9.

Piessens, V., E. Van Coillie, B. Verbist, K. Supré, G. Braem, A. Van Nuffel, L. De Vuyst, M. Heyndrickx, and S. De Vliegher. 2011. Distribution of coagulase-negative Staphylococcus species from milk and environment of dairy cows differs between herds. J. Dairy Sci. 94:2933-2944. https://doi.org/10.3168/jds.2010-3956.

Rainard, P., G. Foucras, J. R. Fitzgerald, J. L. Watts, G. Koop, and J. R. Middleton Jr.. 2018. Knowledge gaps and research priorities in Staphylococcus aureus mastitis control. Transbound. Emerg. Dis. 65(Suppl 1):149-165. https://doi.org/10.1111/tbed.12698.

Reiné, J., J. Rylance, D. M. Ferreira, S. H. Pennington, I. D. Welters, R. Parker, and B. Morton. 2020. The whole blood phagocytosis assay: A clinically relevant test of neutrophil function and dysfunction in community-acquired pneumonia. BMC Res. Notes 13:203. https://doi.org/10.1186/s13104-020-05034-0.

Rinaldi, M., P. Moroni, M. J. Paape, and D. D. Bannerman. 2007. Evaluation of assays for the measurement of bovine neutrophil reactive oxygen species. Vet. Immunol. Immunopathol. 115:107-125. https://doi.org/10.1016/j.vetimm.2006.09.009.

Rooijakkers, S. H., W. J. van Wamel, M. Ruyken, K. P. van Kessel, and J. A. van Strijp. 2005. Anti-opsonic properties of staphylokinase. Microbes Infect. 7:476-484. https://doi.org/10.1016/j.micinf 2004.12.014

Santos, B. P., F. N. Souza, M. G. Blagitz, C. F. Batista, H. G. Bertagnon, S. A. Diniz, M. X. Silva, J. P. A. Haddad, and A. M. M. P.
Della Libera. 2017. Blood and milk polymorphonuclear leukocyte and monocyte/macrophage functions in naturally caprine arthritis encephalitis virus infection in dairy goats. Vet. Immunol. Immunopathol. 188:21-26. https://doi.org/10.1016/j.vetimm.2017.04.009.

Santos, R. P., F. N. Souza, A. C. D. Oliveira, A. F. de Souza Filho, J. Aizawa, L. Z. Moreno, A. F. da Cunha, A. Cortez, A. M. M. P. Della Libera, M. B. Heinemann, and M. M. O. P. Cerqueira. 2020. Molecular typing and antimicrobial susceptibility profile of Staphylococcus aureus isolates recovered from bovine mastitis and nasal samples. Animals (Basel) 10:2143. https://doi.org/10.3390/ ani10112143.

Schukken, Y. H., D. J. Wilson, F. Welcome, L. Garrison-Tikofsky, and R. N. Gonzalez. 2003. Monitoring udder health and milk quality using somatic cell counts. Vet. Res. 34:579-596. https://doi.org/10 .1051/vetres:2003028.

Schutze, G. E., M. A. Hall, C. J. Baker, and M. S. Edwards. 1991. Role of neutrophil receptors in opsonophagocytosis of coagulasenegative staphylococci. Infect. Immun. 59:2573-2578. https://doi .org/10.1128/iai.59.8.2573-2578.1991.

Smits, E., C. Burvenich, and R. Heyneman. 1997. Simultaneous flow cytometric measurement of phagocytic and oxidative burst activity of polymorphonuclear leukocytes in whole bovine blood. Vet. Immunol. Immunopathol. 56:259-269. https://doi.org/10.1016/ S0165-2427(96)05739-X.

Souza, F. N., M. G. Blagitz, C. F. Batista, P. V. Takano, R. G. Gargano, S. A. Diniz, M. X. Silva, J. A. Ferronatto, K. R. Santos, M. B Heinemann, S. De Vliegher, and A. M. M. P. Della Libera. 2020. Immune response in non-specific mastitis: What it can tell us? J. Dairy Sci. 103:5376-5386. https://doi.org/10.3168/jds.2019-17022.

Souza, F. N., M. G. Blagitz, A. O. Latorre, E. M. Ramos Sanchez, C. F. Batista, R. A. Weigel, F. P. Renno, M. C. Sucupira, and A. M. M. P. Della Libera. 2012. Intracellular reactive oxygen species production by polymorphonuclear leukocytes in bovine leukemia virus-infected dairy cows. J. Vet. Med. Sci. 74:221-225. https:// doi.org/10.1292/jvms.11-0246.

Souza, F. N., A. F. Cunha, D. L. S. O. Rosa, M. A. V. Brito, A. S. Guimarães, L. C. Mendonça, G. N. Souza, A. P. Lage, M. G. Blagitz, A. M. M. P. Della Libera, M. B. Heinemann, and M. M. O. P. Cerqueira. 2016a. Somatic cell count and mastitis pathogen detection in composite and single or duplicate quarter milk samples. Pesq. Vet. Bras. 36:811-818. https://doi.org/10.1590/s0100 $-736 \times 2016000900004$.

Souza, F. N., S. Piepers, A. M. M. P. Della Libera, M. B. Heinemann, M. M. O. P. Cerqueira, and S. De Vliegher. 2016b. Interaction between bovine-associated coagulase-negative staphylococci species and strains and bovine mammary epithelial cells reflects differences in ecology and epidemiological behaviour. J. Dairy Sci. 99:2867-2874. https://doi.org/10.3168/jds.2015-10230.

Sousa Marques, M. F., G. Santana de Moura, F. Nogueira de Souza, R. Gomes Gargano, K. R. Santos, J. A. Ferronatto, A. M. M. P. Della Libera, and R. A. Mota. 2021. Blood polymorphonuclear leukocyte responses against Staphylococcus aureus in primiparous and pluriparous Lacaune and Santa Inês ewes. Small Rumin. Res. 201:106412. https://doi.org/10.1016/j.smallrumres.2021.106412.

Spaan, A. N., B. G. Surewaard, R. Nijland, and J. A. van Strijp. 2013. Neutrophils versus Staphylococcus aureus: A biological tug of war. Annu. Rev. Microbiol. 67:629-650. https://doi.org/10.1146/ annurev-micro-092412-155746.

Spiliopoulou, A. I., M. I. Krevvata, F. Kolonitsiou, L. G. Harris, T. S. Wilkinson, A. P. Davies, G. O. Dimitracopoulos, N. K. Karamanos, D. Mack, and E. D. Anastassiou. 2012. An extracellular Staphylococcus epidermitis polysaccharide: Relation to polysaccharide intercellular adhesin and its implication in phagocytosis. BMC Microbiol. 12:76. https://doi.org/10.1186/1471-2180-12-76.

Supré, K., F. Haesebrouck, R. N. Zadoks, M. Vaneechoutte, S. Piepers, and S. De Vliegher. 2011. Some coagulase-negative Staphylococcus species affect udder health more than others. J. Dairy Sci. 94:2329-2340. https://doi.org/10.3168/jds.2010-3741.

Sutra, L., P. Rainard, and B. Poutrel. 1990. Phagocytosis of mastitis isolates of Staphylococcus aureus and expression of type 5 capsular polysaccharide are influenced by growth in the presence of milk. 
J. Clin. Microbiol. 28:2253-2258. https://doi.org/10.1128/jcm.28 .10.2253-2258.1990.

Templeton, G. F. 2011. A two-step approach for transforming continuous variables to normal: Implications and recommendations for IS research. Comm. Assoc. Inform. Syst. 28:41-58. https://doi.org/ 10.17705/1CAIS.02804

Thammavongsa, V., H. K. Kim, D. Missiakas, and O. Schneewind. 2015. Staphylococcal manipulation of host immune responses. Nat. Rev. Microbiol. 13:529-543. https://doi.org/10.1038/nrmicro3521.

Valckenier, D., S. Piepers, A. De Visscher, and S. De Vliegher. 2020. The effect of intramammary infection in early lactation with nonaureus staphylococci in general and Staphylococcus chromogenes specifically on quarter milk somatic cell count and quarter milk yield. J. Dairy Sci. 103:768-782. https://doi.org/10.3168/jds.2019 $-16818$.

Vander Top, E. A., G. A. Perry, and M. J. Gentry-Nielsen. 2006. A novel flow cytometric assay for measurement of in vivo pulmonary neutrophil phagocytosis. BMC Microbiol. 6:61. https://doi.org/10 .1186/1471-2180-6-61.

Vanderhaeghen, W., S. Piepers, F. Leroy, E. Van Coillie, F. Haesebrouck, and S. De Vliegher. 2014. Invited review: Effect, persistence, and virulence of coagulase-negative Staphylococcus species associated with ruminant udder health. J. Dairy Sci. 97:5275-5293. https://doi.org/10.3168/jds.2013-7775.

Vanderhaeghen, W., S. Piepers, F. Leroy, E. Van Coillie, F. Haesebrouck, and S. De Vliegher. 2015. Identification, typing, ecology and epidemiology of coagulase negative staphylococci associated with ruminants. Vet. J. 203:44-51. https://doi.org/10.1016/j.tvjl .2014.11.001.

Wuytack, A., A. De Visscher, S. Piepers, F. Boyen, F. Haesebrouck, and S. De Vliegher. 2019. Non-aureus staphylococci in fecal samples of dairy cows: First report and phenotypic and genotypic characterization. J. Dairy Sci. 102:9345-9359. https://doi.org/10 .3168/jds.2019-16662. 